\title{
Positioning Adat Law in the Indonesia's Legal System: Historical Discourse and Current Development on Customary Law
}

\author{
Bono Budi Priambodo* \\ Amsterdam Institute for Social Science Research, \\ the Netherlands
}

\begin{abstract}
Adat law has been narrowly understood, mainly as part of private law, in the curricula of Indonesian law schools. This is in contrary to the original intent of adat law, both as an academic and policy discourse, at the first place, which was as an attempt to develop a legal system that is suitable to govern the Netherlands East Indies (NEI) for preventing violation against the indigenous sense of justice. This article seeks to clarify the actual purpose of Adat Law, as it conceived, in the living of traditional community and the relation between adat law and Indonesian state law following the Indonesian independence. Subsequently, this article would explore how constitutional law and administrative laws (staatsrecht) would place "Adat law" under the Indonesian legal system that might be well claimed as an autochthonous law of Indonesia. It is a legal writing that uses historical, statutory, and case approaches. It has been found out that Adat Law scholarship had a pragmatic purpose i.e. to administer justice and govern the NEI colony that reflects a characteristic of public law. The later development showed that the law has shifted its focus into private law fields such as the law of persons, marriage and family laws, property and inheritance laws. Such shifting leads Adat law into an obscured relation between Adat Law and public laws in the era of the post-independence of Indonesia. It can be concluded that under historical inquiry, the Basic Law of 1945 (Indonesian Constitution) has strongly inspired by Adat Law. The same goes for administrative law, which in this case is represented by BAL that governs not only land administration but all kinds of natural resources in Indonesia until nowadays.
\end{abstract}

Keywords: Indonesian Adat Law; Constitutional Law; Administrative Law; Legal System; Legal Theory.

How to Cite (chicago-16th): Budi Priambodo, Bono. "Positioning Adat Law in the Indonesia's Legal System: Historical Discourse and Current Development on Customary Law." Udayana Journal of Law and Culture 2, no. 2 (2018): 140-164. https://doi.org/110.24843/UJLC.2018.v02. i02.p02.

DOI: https://doi.org/ 10.24843/UJLC.2018.v02.i02.p02

\section{Introduction}

During the Conference on Adat Law ${ }^{1}$ in 2017 in Leiden, the Netherlands, Adriaan Bedner, a Leiden University Professor of Law and Society and an Indonesianist, raised the central question concerning the position of adat in Indonesian land law: 'where are we heading?'. ${ }^{2}$ The second part of the conference addressed the academic

E-mail/Corresponding Author: b.b.priambodo@uva.nl ; bonoharnowo@gmail.com

Term 'adat law' refers to customary law that is practiced by traditional community in Indonesia. The law is created and implemented in autonomous and peculiar ways by highly respecting local wisdom and tradition.

2 Jacqueline Vel and Willem van der Muur, Report of the Conference 'Adat law 100 years on: towards a new interpretation?' National Museum of Ethnology Leiden, released in October 2017: 4.<https:// www.universiteitleiden.nl/binaries/content/assets/rechtsgeleerdheid/instituut-voor-metajuridica/conference-report---adat-law-100-years-on.pdf> 
debate regarding the concept, use and current relevance of adat. Keebet von BendaBeckmann, a scholar from Max Planck Institute for Social Anthropology, Halle-Saale, Germany, addressed the value of Van Vollenhoven's analyses in light of current struggles over resources and explained that his work on customary law in the Dutch East Indies stemmed from his concern on the ways the colonial government dealt with it. ${ }^{3}$

The stereotype of adat law in the Indonesia's constitutional law and administrative law-or, in other words, the way in which constitutional law and administrative law perceive adat law-is perhaps already well-known to most scholars. Since it has been initiated by Law Number 5 Year 1960 on the Basic Regulation of the Essentials of Agrarian Affairs (or more renowned, and subsequently called as the Basic Agrarian Law /BAL), adat law is recognized "as long as in reality still exist" 4and "does not in conflict with the State interest." 5 Each and every administrative law in Indonesia, particularly those pertaining to the management of natural resources, follows this pattern of policy. Even, the Second Amendment to the Basic Law of $1945^{6}$ follows such model by stipulating the idea that "the State acknowledges jural communities and their traditional rights as long as they still live and in accordance with advancements in the society and the principle of Unitary state of the Republic Indonesia, to be further stipulated by law." 7 However, the continuing process of the agrarian reform seems face some obstacles, such as conflict between traditional rights and the modern, Western-influenced, various interests and purposes of the state.

In the forestry sector, particularly with regard to the act of state on conducting control over forests, the rights of jural communities is limited to the actual existence of the community. shall be considered "as long as in reality still exist and its existence is recognized, as well as not in conflict with national interest." ${ }^{\text {Accordingly, }}$ pertaining to plantation, if the land to be used for that purpose "is ulayat land

$3 \quad$ Ibid.6.

4 Law Number 5 Year 1960 on the Basic Regulation of the Essentials of Agrarian Affairs (Basic Agrarian Law /BAL) Art. 3.

5 Ibid. Art. 5.

6 The term "Undang-Undang Dasar" is usually translated into Constitution. However, I intentionally translate it into "Basic Law" to match the term used in the "Elucidation to the 1945 Basic Law," which will be discussed and elaborated later in this article.

7 Second Amendment to 1945 Basic Law. Art. 18B.2. The term jural community is used to translate kesatuan masyarakat hukum adat (bahasa Indonesia) and rechtsgemeenschap (Dutch), that refers to customary community that implements its own customary rules.

8 Law Number 41 Year 1999 on Forestry. Art. 4.3. This clause however has been amended pursuant to Minister of Forestry Circular No. SE.1/Menhut-II/2013 j.o. Constitutional Court Decision No. 35/PUUX/2012 dated 16 May 2013 concerning judicial review of the consitutionality of several articles in 1999 Forestry Law, particularly pertaining to the stipulation that adat forests (hutan adat) are state forests (hutan negara) managed by jural communities. According to the Circular, the stipulation only applies to jural communities whose existence is not yet confirmed by a regional regulation. (peraturan daerah) If its existence is already established by a regional regulation, Ministry of Forestry, or, currently Ministry of Environmental Affairs and Forestry shall thus establish the status of forest area claimed by the jural community as their ulayat right as adat forest pursuant to Regulation of Ministry of Environmental Affairs and Forestry Number P.32/Menlhk-Setjen/2015 on Forests Subject to Rights. 
belonging to a jural community which in reality still exist," the granting of right over the land shall be preceded by "consultation with the jural community as the holder of hak ulayat (right of allocation; beschikkingsrecht) and its members that hold any rights over the land, shall reach an agreement concerning transfer of land and its compensation." 9

\subsection{Purpose}

This article seeks to firstly clarify the actual purpose of Adat Law and the relation between adat law and Indonesian national law following the independence. Subsequently, this article attempts to explore how constitutional and administrative law (staatsrecht) would be situated in an "Adat" legal system that might well be claimed as an autochthonous law of Indonesia. ${ }^{10}$ It is not about "stereotype" as previously explained in the Background. On the contrary, it discusses the other direction i.e. how would Adat Law ${ }^{11}$ recognizes Indonesian constitutional and administrative law, as laws that govern the formation and the working of the state (staatsrecht). To a large extent, this question is far more relevant and makes more sense, because Adat Law is a legal system of its own while constitutional law and administrative law are only fields of law.

\subsection{Method}

This writing explores legal philosophy and concepts of Adat Law. It uses a historical approach to look back on how Dutch government and scholars initiated Adat Law as well as to discover legendary debates on the position of Adat Law in the Indonesia's legal system by Indonesian leaders and legal scholars before and after the independence of the state of Indonesia. Besides, this paper also employs a statutory approach in analyzing relevant law and regulations while resources are obtained from textbooks, journals, and reports. It also applies a case approach, particularly in analyzing the decision of the Indonesian Constitutional Court on the issue of jural community rights over their customary lands.

9 Law Number 18 Year 2004 on Plantation, Art. 9.2. As an impact of the Constitutional Court Decision mentioned above, this clause, too, is amended in 2014, scrapping the words "which in reality still exist" vide Law Number 39 Year 2014 on Plantation, Art. 12. The Decision itself, I think, is somewhat awkward. If legislative stipulations requiring recognition to jural communities and their rights to fulfill the conditions of "as long as in reality still exist" and "not in conflict with national interests" are unconstitutional, how come the 1945 Constitution still contain the clauses? Or, in other words, how could those legislative stipulations be unconstitutional if the Constitution itself require the same things?

10 Adat Law as a legal system was the views of Kusumadi Pujosewoyo and Supomo, as discussed in Bushar Muhammad. Asas-Asas Hukum Adat. Suatu Pengantar. Ed. IX. (Jakarta: Pradnja Paramita, 1994),16-17, while Adat Law as Indonesian autochthonous law (hukum aseli Indonesia) was Supomo's opinion further developed by Kusnu, as discussed in Iman Sudiyat. (2000) Asas-asas Hukum Adat: Bekal Pengantar. Ed. III. (Yogyakarta: Liberty, 2000), 105.

11 In this article, I differentiate between Adat Law and adat law(s). I write Adat Law with capitalization in each word when I refer to adat law as concepts and principles that are considered as "universal" throughout Indonesian archipelago, while adat law(s) in lower case, sometimes in plural, refer to the actual laws that live among the people.This is in line with M.Kusnu's differentiation between adat law in expert's sense and in lay people's sense. 
The structure of this article can be described as follows. The introductory section exposes the background, aims of writing, the method of the research, and the relevant literature supporting, or providing insights into the ideas of this writing. The section of result and analysis started with a discussion on the actual purpose of Adat Law that developed during the colonial times. Afterwards, the position of Adat Law in the national legal system in the independent state of Indonesia is discussed. Historical and scholarly debates were revisited to reaffirm that Adat Law is indeed an integral part of the Indonesian state law.

The analysis then continues to an inquiry to ideas behind the deliberations of the Basic Law of 1945 which very much inspired by Adat Law. Subsequently, a discussion concerning the relation between adat Law and administrative law, under the issue of land law has been forwarded. BAL shall be examined, since the law has been claimed as, among others, the national agrarian law is based on adat law concerning land; and, furthermore, "Agrarian law applicable to land, water and airspace is adat law." The result of the analyses has been drawn up in the section of conclusion for framing and sharping the ideas of the writing.

\subsection{Literature Review}

Researches on customary laws generally discuss on how custom and tradition may be recognized and used in practice as a source of law, ${ }^{12}$ including the way authorities regarded them as binding rules with its quasi-nature. Customary laws have been analyzed from various perspectives, such as socio-legal studies, especially the anthropology of law, ${ }^{13}$ constitutional law, ${ }^{14}$ legal pluralism, ${ }^{15}$ and human rights. ${ }^{16}$ Scholars were also interested in discussing it in more thematic issues, for example, enforcement of the customary law, ${ }^{17}$ traditional community and indigenous peoples, ${ }^{18}$ or customary inheritance rights. ${ }^{19}$

12 Morsen Mosses, "Custom as a Source of Law in Vanuatu: A Critical Analysis," Journal of South Pacific Law, Special Edition (2017).

13 Tien Handayani Nafi et.al., "Peran Hukum Adat dalam Penyelesaian Kasus-Kasus Kekerasan terhadap Perempuan di Kupang, Atambua, dan Waingapu", Jurnal Hukum \& Pembangunan 46, no. 2 (2016): 233234.

${ }^{14}$ Datu Bua Napoh, "Recognition of the Customary Land Law in the Constitution of Indonesia and Malaysia," Brawijaya Law Journal 2, no.2 (2015).

15 Robin Perry, "Balancing Rights or Building Rights? Reconciling the Right to Use Customary Systems of Law with Competing Human Rights in Pursuit of Indigenous Sovereignty," Harvard Human Rights Journal 24, no.1 (2011): 73-75.

16 Ibid., 83-113.

17 Jeanmarie Fenrich and Mary McEvoy, "Promoting Rule of Law in Customary Tribunals in Ghana," Harvard Human Rights Journal 11 (September 2014).

18 Lillian Aponte Miranda, "Indigenous Peoples as International Lawmakers," University of Pennsylvania Journal of International Law 32, no. 1 (2010)

19 Budi Prasetyo, "Contribution of Adat Law in the Reform and Development of National Inheritance Law in Indonesia", South East Asia Journal of Contemporary Business, Economics and Law 15, no.5 (April 2018). 
Mirza Satria Buana has conducted research on the practices of legal pluralism in Indonesia, especially from philosophical, social and legal perspectives. ${ }^{20} \mathrm{He}$ argued that the idea of implementing strong legal pluralism is rather naive, and thus, considered that state legal pluralism is more feasible and realistic, and therefore should be enforced. ${ }^{21}$ Regarding adat law, his writing expresses disagreement to the concept established by Ter Haar concerning four requirements for legally-based indigenous peoples ${ }^{22}$ by considering that these may lead to a false dichotomy between culturally-based indigenous peoples and legally-based indigenous peoples. He considers the concept as a fallacy, so the concept of the legally-based indigenous peoples currently used by the Indonesian Constitution and legislation may lead to discrimination. ${ }^{23}$

Nurjaya employes legal anthropology approach to finding another atmosphere in building a better, more holistic understanding on whether the 1945 Basic Law defines a genuine or pseudo-recognition and protection of adat communities and their traditions, especially concerning rights to, and tenure of, natural resources. ${ }^{24}$ When assessing provisions contained in some legislation, i.e. BAL and Laws on Forestry, Spatial Use, Water Resources, Coastal Zone and Small Islands Management, Mineral and Coal Mining, and Environmental Protection and Management, he highlights the conditional phrase "as long as" with regard to the recognition and respect of the adat society. ${ }^{25}$ In his view, it obviously leads to restrictions on, and neglect of, the rights of adat communities to control, manage and utilise the natural resources they depend on for survival in the territory and entails that customary environmental wisdom is automatically dominated and subordinated by the national legislation over natural resources. ${ }^{26}$ The continuous neglect and abuse have encouraged adat communities to push for a law regulating and protecting their rights. ${ }^{27}$

Kallie Szczepanski is a bit sceptical on how law and policies of land in Indonesia would be in favour of adat communities' interests. Szczepanski views that "BAL pays lip service to adat while ensuring that it can be preempted at will by the

20 Mirza Satria Buana, "Living adat Law, Indigenous Peoples and the State Law: A Complex Map of Legal Pluralism in Indonesia," International Journal of Indonesian Studies 1, no. 3 (2016): 105.

21 Ibid, 116. See also Mirza Satria Buana, "State Courts, Traditional Dispute Resolution and Indigenous Peoples in South Kalimantan: A Socio-Legal Study" (Ph.D diss., TC Beirne School of Law, University of Queensland, (2017), 30.

22 Ter Haar requires the following, (1) The community has well organised groups; (2) The community has its own territory; (3) The community has its own tribal institution (in particular a tribal court); and (4) The community has both material and non-material (spiritual) goods.

23 Mirza Satria Buana, Op. Cit., 107.

24 I Nyoman Nurjaya, "Is the Constitutional and Legal Recognition of Traditional Community Laws within the Multicultural Country of Indonesia a Genuine or Pseudo Recognition?,"Constitutional Review 1, no.2 (December 2015): 52.

25 Ibid., 54-55.

26 Ibid., 55.

27 Moses Ompusunggu, 'Adat' Communities Want their own Special Law: Why?, The Jakarta Post, May 11, 2018. 
slightest governmental interest. As indigenous rights and law are weakened, the national government gains an ever-greater ability to deprive indigenous peoples of their lands." 28 In addition, Szczepanski assessed that Indonesia's laws and policies lead directly to despair and violence for the displaced indigenous peoples of the outer islands. ${ }^{29}$ Daniel Fitzpatrick argues that "BAL in practice is not a syncretic amalgam of Western and adat principles but instead operates contrary to adat, particularly in its imposition of Western-style, individualized land titles on customary forms of tenure". ${ }^{30}$ This inconsistency with adat has two fundamental consequences. First, the process of registering titles under the BAL itself creates long-term disputation and social conflict, and, for that reason, is highly unlikely to fulfill its objective of legal certainty. Second, the BAL's failure to provide legal certainty, in combination with the erosion or subjugation of adat authority in many areas, have created a dangerous legal vacuum and allowed ad hoc bureaucratic fiat to dominate the administration and development of land in Indonesia.

\section{Result and Analysis}

\subsection{The Actual Purpose of Adat Law}

It is important to firstly clarify the background and actual purpose of introducing Adat Law discourse as well as criticizing the fact that Adat Law, up until recently, concerns mainly-or even is identical with-private laws; particularly in the curricula of legal higher educations in Indonesia. ${ }^{31}$ This clearly is not in accordance, not only with recent developments but also with its background, where adat law inquiries and discourses were paramount both in academic and policy realms for a very pragmatic purpose i.e. governing the colony. A proof can be presented here from as early as 1842 when Dutch Minister of the Colonies J.C. Baud stated the following.

"[it was] a manifest truth that a subjected people cannot, in the long run, be kept in subjection without violence unless the foreign ruler was determined to govern this people with fairness and justice and, above all, in deference to native attitudes, customs and bias." 32

28 Kallie Szczepanski, "Land Policy and Adat Law In Indonesia's Forests," Pacific Rim Law \& Policy Journal 11, no.1 (January 2002): 241.

29 Ibid., 255.

30 Daniel Fitzpatrick, "Disputes and Pluralism in Modern Indonesian Land Law," Yale Journal of International Law 22, no. 1 (1997): 173.

31 This tendency was observed by, among others, Suryono Sukanto and Soleman Taneko. Hukum Adat Indonesia. (Jakarta: RajaGrafindo Persada, 2003), 117. The first print of the book was in 1981) as follows, "Nowadays, evident in the curricula of law schools in Indonesia, an unsuitable systematic is being "forced" which is contrary to the living reality of nowadays adat law, where Adat Law course is always understood as comprising of only adat private laws."

32 Cess Fasseur. "Colonial Dilemma: Van Vollenhoven and the Struggle Between Adat Law and Western Law in Indonesia," in European Expansion and the Law, ed. Wolfgang J. Mommsen, and Jaap A. de Moor (Oxford/New York: Berg, 1990), 241-242. 
In fact, it was this kind of attitude or anything like it that later triggered a protracted debate over how the Netherland East Indies (NEI) should be governed. On one hand, there was an idea that NEI should be governed under a legal system that consists of decisions which are issued and enforced by superior authorities that are recognized just like that. On the other hand, there was this idea that emphasizes on justice for the people, where the legal system is a set of institutions unanimously known, recognized and enforced among the people, by the people themselves ${ }^{33}$-an idea that later was elaborated into Adat Law. In the words of van Vollenhoven, the father of Adat Law scholarship himself, the purpose of the scholarship is "the creationnot on paper but in reality - of a good administration of justice and a good system of government." 34 From the very beginning-more than just academic studies on private laws-Adat Law was understood as (i) a legal system, and,(ii) means of governance.In other words, in the late 19th century and early 20th century, the Kingdom of Netherlands looked for a solution to governance problems in the NEI, and the chosen solution, as the history would attest, was Adat Law. Even nowadays, as von Benda-Beckmann puts it;

"The discussions about the interpretation of adat law and ulayat rights were always much more than mere academic exercises. They concerned the legitimation of political and economic power over natural resources and the question on which law the road to'development' was to be built."35

It can, therefore, be concluded that Adat Law discourse is essentially a discourse concerning legal system and governance that is continuously relevant from the time it was introduced to recent times. It is indeed disheartening when Adat Law nowadays fossilizes within the curricula of law schools in Indonesia only as a part of private laws-as one of its varieties i.e. "Western," Islamic, Adat private laws and now, economic laws. ${ }^{36}$

\subsection{Adat Law is National Law}

Since1927, after previously being ignored,even oppressed under the concordance principle and unification policy, indigenous adat laws finally prevail as the only laws

33 Peter Burns. The Leiden Legacy. Concepts of Law in Indonesia (Leiden: KITLV Press, 2004), xv.

34 JF, Holleman, (Ed.) Van Vollenhoven on Indonesian Adat Law (Dordrecht: Springer Science, Business Media, 1981), XXI.

35 Franz Von Benda-Beckmann,and Keebet Von Benda-Beckmann (2011) "Myths and Stereotypes about Adat Law. A Reassessment of Van Vollenhoven in the Light of Current Struggles over Adat Law in Indonesia." Bijdragen tot de Taal, Land en Volkenkunde 167, no.2-3 (2011): 180.

36 These indeed are subdepartments of Private Laws Department in Universitas Indonesia Faculty of Law. Western laws subdepartment focuses on private laws as stipulated in the Dutch 1838 Burgerlijk Wetboek, (Civil Code) Islamic and Adat subdepartments respectively concerns with Islamic and Adat private laws, while Economic laws develops from Dutch 1924 Wetboek van Koophandel (Commercial Code) and its further development in the forms of corporate law, banking law, investment law, and other standard topics of business laws. Some Indonesian scholars recognize the link between Adat law and Islamic law. See for example review on Hazairin thought in Sukiati, "Hazairin's Legal Thought And His Contribution Towards The Indonesian Legal System," Journal of Indonesian Islam 6, no.1 ( 2012) 
applicable to indigenous population in NEI; while for other population groups, their own laws shall prevail respectively. ${ }^{37}$ NEI colonial government from that time on abandoned unification policy and "tended to document adat laws from one locality to the others." Concerning legal policy at that time, Iman Sudiyat provides following explanation.

"Laws applicable to indigenous Indonesians were established after investigation to their actual legal needs; and when it was evident that adat law cannot yet be abandoned or replaced with other laws, the necessary adat law was preserved." 38

Nevertheless, after the proclamation of independence, lawyers from among Indonesians themselves started to speculate on a distinct national legal system for independent Indonesian state, where in general they debated over what must be done to the colonial legacy of the pluralistic legal system. ${ }^{39}$ Bushar Muhammad claimed that "most of them wanted to have a modern unified law" for a national legal system; while the rest, ever loyal to colonial policy from 1927, did not see a possibility to that direction and wanted "legal codification for respective population groups." 40

A noteworthy post-independence Adat Law theory was put forward by no other than Supomo himself, who in 1941 replaced Ter Haar as professor of adat laws in Rechtshoogeschool, Batavia. Dubbed by Otje Salman as "ideologization of Adat Law,"41 Supomo used Adat Law concept of the communal trait ${ }^{42}$ to construct a distinct staatsidee or theory of the state that he called "negara [yang] integralistik," or integralist state, as follows.

"in the situation of unity between leader and the people, among groups of people, all groups will be embraced by the spirit of gotong-royong, (communal mutualism) the spirit of kekeluargaan. (familyhood) It is therefore clear that if we want to establish an Indonesian state that is in accordance with the unique characteristics and traits of Indonesian people, then our state must be based

37 Iman Sudiyat,Op.Cit. 93-94.See also Bushar Muhammad,Op.Cit. 173-174.

38 Iman Sudiyat, Op.Cit. 93.

39 Some scholar may also argue that Indonesia's independence sought efforts to reintroduce and acknowledge not only adat law, but also Islamic laws as part of Indonesia's Legal System. See for instance Fajri Muhammadin and Danusatya, Hanindito, 2017. "De-Secularizing Legal Education in Indonesia: Examining the 'Introduction to Jurisprudence' Textbooks on Norm Classification" in E-Proceedings International Seminar on Islamic Civilization and Thoughts, November 20, 2017, 51-59, Pulau Pinang: School of Humanities Universiti Sains Malaysia: 53.

40 Bushar Muhammad.Op.Cit. 179.

41 Otje Salman Soemadiningrat. Rekonseptualisasi Hukum Adat Kontemporer. (Bandung: Alumni, 2002), 122.

42 This concept originated from inauguration speech by F.D.Holleman as professor of adat laws in Leiden University in 1935 titled De Commune Trekin het Indonesische Rechtleven (The Communal Trait in the Indonesian Jural Lives) vide Bushar Muhammad.Op.Cit. 44. 
on an integralist theory of the state, (staatsidee) an integralist state, a nation-state that is one with the people, be above and beyond all groups in just any fields." 43

Instead of using "the pure idealization of philosophies of life and the state by the philosophers," Otje Salman commented on this, Supomo "returned to the system of Adat Law," when asked to suggest a philosophical background (philosophische grondslag) for an independent Indonesian State. ${ }^{44}$

Supomo himself is an advocate of unified national law. In an occasion of the first anniversary of Gadjah Mada University Yogyakarta on 17 March 1947, he delivered a speech that was said to "catch the world of Indonesian jurisprudence and beyond by surprise" because it reversed from the 1927 policy; which, as concluded by Iman Sudiyat, is as follows.

"It is inevitable that the people and the state of Indonesia must develop into modern people and state. [However] Modern law is not Dutch law. Instead, it is the law that contains universal modern principles. Codification, as far as possible, must be in a unification nature, particularly in the field of property law. Unification, on the other hand, is still difficult in the field of family law, because it is strongly related with, and influenced by, spiritual beliefs from respective groups of people. [All being told] Adat Law will still provide the building blocks for the structuring and development of this new law." 45

This kind of logic and those that leads to this direction are followed in a policy proposal submitted by Dewan Perancang Nasional (Depernas; National Development Planning Agency) in 1959, which took as its stance that the only legal system which is suitable and supportive to the development of a national legal system is Adat Law, because it is conformable with national character. This proposal was later adopted by Majelis Permusyawaratan Rakyat Sementara (Provisional People's Consultative Assembly) in its Decree No. II/MPRS/1960 on the Broad Guidelines of the First Phase of Universal National Development Plan1961-1969, which, among others, stipulated that Adat Law is the foundation of the national legal system, in which;

(1) Adat Law is no longer only a part of national law i.e. unwritten part, but the national law itself, both written and unwritten;

(2) Adat Law is no longer understood as unwritten law originating from local customs; and,

43 Sekretariat Negara RI. Risalah Sidang Badan Penyelidik Usaha-Usaha Persiapan Kemerdekaan dan Panitia Persiapan Kemerdekaan Indonesia (Jakarta: Sekretariat Negara RI, (1992), 30.

44 Otje Salman Soemadiningrat. Op.Cit., 124.

45 Iman Sudiyat, Op.Cit. 95. 
(3) Adat Law shall be extrapolated to a higher plane i.e. national, so that it will be of an abstract nature and contains values applicable generally to all citizens of Indonesia and throughout the territory of the Republic of Indonesia. ${ }^{46}$

Mohammad Kusnu provided a theoretical justification for such legal policy, when he understood adat law in two senses, which are (i) lay people's sense; and, (ii) expert's sense. Adat law in lay people's sense basically is the same with the way it was understood during colonial times i.e. customary institutions that are used by the people to solve their daily lives' problems. Meanwhile, Adat Law in expert's sense refers to its "abstract-normative" aspects, in the form of values that "live, believed, internalized and upheld" by the people and inspire the customary institutions. Adat in this sense "is situated in the spiritual world as values that contain normative legal sense and aspiration." 47 It is this Adat Law in expert's sense that contains "an integral unity of normative principles in accordance with the cultural mindset of Indonesian people," which according to Kusnu is "the normative system [that] shall serve as the reference or foundation of the format and materials of national law." 48

\subsection{An Adat Law-Inspired Constitution}

Thanks to the authoritarian New Order regime's exploit of his Integralist State theory, Supomo the legal theorist is exceptionally notorious to the outside world, even among Indonesian lawyers. ${ }^{49}$ This, I would argue, is gravely unfair because foreign observers usually focus their attack only on his speech on 31 May 1945 while overlooking his other few-but-very-important works. The 1945 Basic Law

46 Iman Sudiyat,Op.Cit.103-104.

47 Moh. Koesnoe. Hukum Adat sebagai Suatu Model Hukum. Bagian I (Historis). (Bandung: Mandar Maju, 1992), 83.

48 Ibid. 148.

49 For years, Supomo has been incessantly bullied by a host of writers, foreign and Indonesian alike. Some of recent examples are, to name but a few, J. Gillespie, "Public discourse and Constitutional Change: A Comparison of Vietnam and Indonesia," Asian Journal of Comparative Law 11, no 2 (2016); Damos Damoli Agusman, "The Dynamic Development on Indonesia's attitude toward International Law." Indonesian Journal of International Law 13, no.1 (2015); Agus Wahyudi. "Human Rights and Corruption: Indonesian Case for Reconciling Universalism and Relativism." in Subrata Sankar Bagchi and Arnab Das (Eds.) Human Rights and the Third World: Issues and Discourses. (Lanham: Lexington Books, 2013). There are at least two monographs dedicated almost exclusively to this end i.e. D. Bourchier. Illiberal Democracy in Indonesia: The Ideology of the Family State. (London: Routledge, 2015) and Marsilam Simanjuntak, Pandangan Negara Integralistik: Sumber, Unsur dan Riwayatnya dalam Persiapan UUD 1945 (Jakarta: Pustaka Utama Grafiti, 1994). On the other hand, sympathetic voice concerning Supomo's thoughts, as well as those of other Indonesian Adat legal scholars on post-independence Adat Law is a valuable rarity. Hooker (Michael Barry Hooker, Adat Law in Modern Indonesia. Oxford: Oxford University Press, 1979) is perhaps the only example of this rarity, even though he could not escape harsh critics for his views. David M. Engel, "Adat Law in Modern Indonesia." The American Journal of Comparative Law 28, no. 2 (1980): 352 354, https:// doi.org/ $10.2307 / 839892$ 
and-particularly-its Elucidation, ${ }^{50}$ for instance, is arguably the pinnacle of his career as a lawyer and legal theorist as well. If only van Vollenhoven were still alive in 1945, he would have found out that his hope of the emergence of Indonesian Blackstone, Grotius or Euripides fulfilled by Supomo-although not exactly like what he had wished for. ${ }^{51}$ Supomo had succeeded in elaborating a constitution for independent Indonesia that is based solely and purely on Adat Law as the autochthonous law of Indonesians.

His faith in Adat Law is unwavering, conspicuous right from the very first sentences of the Elucidation to 1945 Basic Law, when he said the following.

"The Basic Law of a State is only a part of the constitution of the State. The Basic Law is the written [codified] constitution, while complementing the Basic Law is the unwritten [uncodified] constitution i.e. basic rules that emerge and are preserved in the State management practices, although unwritten."52

How can we understand this statement? There can be no other way to do so but to have at least a minimum understanding of Adat Law discourses. Not only that these adat law scholars observed unwritten or uncodified legal rules as the main feature of adat laws, ${ }^{53}$ they indeed have faith in the virtue of uncodified law, particularly because of their understanding of law as the "living law." 54 That is why Supomo in the Elucidation insisted that examining only the texts of a basic law will

50 Anthony Reid mentioned Supomo as "Van Vollenhoven's most influential student" and " the principal author of the Indonesian Constitution,"("Political"tradition"in Indonesia: the one and the many." Anthony Reid, "Political "Tradition" in Indonesia: the One and the Many," Asian Studies Review, 22, no.1(1998): 26. While Elson in a note, stated that the Elucidation to 1945 Constitution "[was] the work of Supomo, [although it] did not emerge formally until its publication in the official Berita Republik Indonesia on 15 February 1946." Robert Edward Elson, The Idea of Indonesia. A History (Cambridge: Cambridge University Press, 2008). The version of the text of Elucidation to 1945 Basic Law referred in this Article is the one included in Presidential Decree 5 July 1959 which was later published as part of Dewan Pertimbangan Agung RI. Tudjuh Bahan Pokok Indoktrinasi. (Jakarta: DPA RI, 1961).

51 Holleman, J.F. Op.Cit. 261. In 1931, van Vollenhoven argued that the future of Adat Law will be decided not by "a Dutchman. [himself?] Only a Buginese or Javanese Blackstone, a Minangkabau or Balinese Grotius, could do this. And might not... that even enhance a national sense of justice, such as Euripides inspired among the Hellenes?" He mentioned Blackstone, Grotius and Euripides in reference to their works in preserving and developing British, Dutch and Greek "Adat Law" respectively. What happened was not exactly like that, because Buginese, Javanese, Minangkabau, Balinese and all other "nations" in ex-NEI apparently succeeded in 1945 to realize their Oath in 1928 to unite as one nation i.e. Indonesia; hence, Supomo as Indonesian Blackstone, Grotius, or Euripides.

52 Supomo differentiated between "undang-undang dasar" (Dutch: grondwet, German: grundgesetz, English: basic law) and "hukum dasar." (constitution) He also made references to French terms loi constitutionelle as equivalent to "hukum dasar" and droit constitutionelle as equivalent to "undang-undang dasar." Translating Undang-Undang Dasar 1945 into 1945 Constitution, if what one means is the texts, is therefore, according to Supomo, incorrect. Instead, it should be referred to as 1945 Basic Law.

53 Supomo. Bab-bab tentang Hukum Adat (Jakarta: Penerbitan Universitas, 1962), 3. See, Holleman, Op.Cit. XLII.

54 Ibid. 2, 5. A very good example of this stance is demonstrated in a mini-publication by MM. Joyodiguno. Reorientasi Hukum dan Hukum Adat (Jogjakarta: PT. Penerbit Universitas, 1961). 
not lead one to a comprehensive understanding of a state's constitution. Instead, one must investigate two things: firstly, how the constitution is practised in real life; and, secondly, the "geistlichen hintergrund"or the spiritual background of the texts, how and in what situation the texts were formulated. ${ }^{55}$

In this regard, there are two strong arguments posed by Supomo on why the emphasis must be on the uncodified constitution. Firstly, it is in the uncodified constitution, that "spiritual background," the spirit of the people, (volkgeist) or national character will be best maintained and preserved, to ensure that the Law is always in harmony with the people's sense of justice. ${ }^{56}$ Secondly, uncodified constitution, on the other hand, will also best ensure that laws are keeping up with the dynamics of societal development so that laws will never be "verouderd" (obsolete) Codified constitution, therefore, must be "brief and elastic," containing only "essential rules that serve as a broad guideline of instructions on how to manage the State and social welfare." ${ }^{57}$ Finally, for Supomo, it is that spirit of the people which is the real constitution of a state, as follows.

"What is most important in the governance and life of a State is the spirit, the spirit of the State officials, the spirit of government officials. Although the Basic Law is said to be based upon the Spirit of Familyhood, (Semangat Kekeluargaan) when [in fact] the spirit of the State and government officials is that of individualism, (perseorangan) the Basic Law will mean nothing in practice. On the other hand, although the Basic Law is imperfect, if the spirit of the officials is good, [i.e. that of Familyhood] that [imperfect] Basic Law will not be an obstacle in the running of the State. Spirit, therefore, is the most important thing, the Spirit that lives, or is, in other word, dynamic." 58

From this point on can one only depart to Supomo's later ideas on the development of Indonesian national legal system; otherwise, one will be lost. Indeed, in 1947 he proposed unification for modern Indonesian national law; which was "surprising" because it was almost like a sacrilege to adat law scholarship. However, this 'sacrilege' has in fact been done later in the Elucidation to 1945 Basic Law. In other words, if one examines Supomo's ideas in the Elucidation, any development in his later thoughts is no surprise at all. For instance, on an occasion of "Southeast Asia Conference" in Washington on 14 August 1952, he presented a paper titled "The future of adat law in the reconstruction of Indonesia," where he provided the following explanation concerning the situation of adat law in colonial times.

"Adat laws are non-statutory laws most of which are customary laws and a small part of Islamic law. Adat laws also include case laws based on judges' decisions

55 DPA RI. Op.Cit. 53.

56 Holleman, J.F. Op.Cit. 260.

57 DPA RI. Op.Cit. 55. On the relation between Adat Law, state and social welfare, see also MM Joyodiguno. Op.Cit. 14.

58 DPA RI. Op.Cit., 56. Italic by me. Here Supomo made a reference to his speech on 31 May 1945 regarding the Spirit of Familyhood. 
that contain legal principles applicable in respective jurisdictions. Adat law finds it roots in traditional culture. Adat law [therefore] is a living law, because it is an actual manifestation of people's sense of justice. According to its own inner quality, adat law continually in a state of growth and development just like the life itself." 59

These ideas were later elaborated in a posthumous mini publication in 1959 titled "The status of Adat Law in the future," where Supomo proposed the following "to avoid confusion" between adat laws understood during colonial times and how the term should be understood in independent Indonesia.

"the term "Adat Law" shall be used as a synonym of (i) non-statutory law in legislative rules, (ii) case laws from judges' decisions, (iii) laws that live as conventions among state organs, [and] (iv) laws that live as customary rules preserved in the life interaction both in cities and villages. These are all Adat Law."60

\section{Constitution of Indonesia}

$\left.\begin{array}{l|l}\text { Written } & \text { Unwritten } \\ \hline \text { Basic Law } & \text { Convention } \\ \hline \text { Laws } & \begin{array}{l}\text { Non-statutory Laws } \\ \text { Case laws } \\ \text { Customary Laws }\end{array}\end{array}\right\} \begin{gathered}\text { Spirit of Familyhood } \\ \& \\ \text { Consultative Basis }\end{gathered}$

\section{Figure1. Constitution of Indonesia according to Supomo}

If all these information are taken together, we can conclude how Indonesian constitution ought to be, according to Supomo. First, just like an adat legal system would be, ${ }^{61}$ it mostly is an unwritten constitution; although a small part of it is a "brief and elastic" written Basic Law that will be detailed further, where necessary, in statutory Laws or legislation. Complementing, or rather, as the major part of the constitution are unwritten or uncodified laws, as follows.

1. Convention, or the "living" constitution i.e. customs that emerge and develop within the interactions between state organs or official. This will complement-or rather, crystalize into- the written basic law.

2. Non-statutory laws i.e. customs that emerge and develop from interactions among administrative organs as well as between them and the People in realizing State purposes. This will complement the statutory laws or legislation.

59 Supomo. "The Future of Adat Law in the Reconstruction of Indonesia," in Southeast Asia in the Coming World, ed. Philip Warren Thayer (Baltimore: John Hopkins Univesity Press, 1957).

60 Supomo. Kedudukan Hukum Adat di Kemudian Hari (Jakarta: Pustaka Rakyat, 1959), 29-30.

61 Otje Salman Soemadiningrat. Op.Cit., 125. on this he commented, "because of [Supomo's] eagerness to preserve the genuine Indonesian characteristics...” 
3. Case laws i.e. judge's decisions that contain legal principles applicable in their respective jurisdictions.

4. Customary laws i.e. laws that live as customary rules preserved in the life interaction among the People.

Most importantly, it is in these uncodified laws the Spirit of the Peoplethat might be formulated as (i) Familyhood Principle (Asas Kekeluargaan) or Communal-mutualism; (Gotong-royong) and, (ii) Consultative Basis (Dasar Permusyawaratan) ${ }^{62}$ - will live, be nurtured and flourish, because the Spirit- and, therefore, the Law-must live dynamically.

\subsection{National Land Law is Adat Law}

In a speech titled "The Rediscovery of Our Revolution" to commemorate the Independence Day of Indonesia on 17 August 1959, President Soekarno asserted the following.

"Likewise, pertaining to land. We inherited from Dutch [colonial] era several things that we must eradicate, among others, what is known as eigendom (ownership) over land. From now on we delete completely eigendom over land from Indonesian land law. It is unjustifiable, in independent Indonesia, a plot of land is owned by foreigners in casu Dutch! We only recognize ownership over land by Indonesians, in accordance with Article 33 of the 1945 [Basic] Law."63

The next year i.e. on 24 September 1960 the BAL was enacted, stipulating that national agrarian law is based on adat land law and agrarian law applicable to land, water and air space is adat law; ${ }^{4}$ because it is adat law, as the autochthonous law of Indonesians, that is "conformable with the legal sense of common people," and "because most Indonesia people are subject to adat law."65 Budi Harsono'stheories concerning "the Communalist-religious Concept of Adat (Land) Law"66 and "Functional Relation between Adat Law and National Land Law"67 might be best to help us fully understand the intention of those stipulations. To build his theories, Budi Harsono firstly calls to attention that adat law manifests in two features i.e. (i) a set of unwritten positive norms; and, (ii) legal concepts and principles which are the manifestation of people's legal awareness. ${ }^{68} \mathrm{He}$ admitted that as legal norms adat law comes in a variety of contents, "however it is mainly confined to the fields of family and inheritance law." On the other hand, "in the field of land law basically

\footnotetext{
62 Iman Sudiyat, Op.Cit., 101.

63 DPA RI. Op.Cit., 126.

64 See Section 1.1

65 BAL. Penjelasan Umum, III. 1. A.
}

66 Budi Harsono. Hukum Agraria Indonesia. Sejarah Pembentukan Undang- Undang Pokok Agraria, Isi dan Pelaksanaannya. Jilid 1 Hukum Tanah Nasional.Cet. IX. (Jakarta: Djambatan, 2003), 181.

67 Ibid., 204. This part indeed is dedicated to discussing Budi Harsono's theories concerning these topics.

68 Ibid. 179. See also Section 2.2., notice the close similarities between this argument with that of Mohammad Kusnu's. 
there is uniformity, because [it] manifests from the same legal concepts and principles." This, therefore, opens an opportunity for unification based on the adat land law. ${ }^{69}$

Based on this argument, Budi Harsono builds his theory of "Functional Relation." Adat law-whichis claimed by BAL as the basis,even the very national land law itself-actually is the "main source" of national land law, in a sense that national land law is developed from the concepts and principles of adat law; while adat law in the form of norms serves as complement to positive national land law. ${ }^{70}$ After clarifying this point, Budi Harsono proceeded to the theory of "Adat Law concept" that he understood as a "communalist-religious" concept that "allows individual control over land based on individual rights, while at the same time contain communal elements."71 The land is understood as the gift from the Almighty God, in the first place, to the people as a unity, to subsequently be used individually by the members of the community. It is this legal relation-that forms between the people as a unity and their land-that is understood as Hak Ulayat or right of allocation. The right of allocation has two aspects, as follows;

(i) Private aspect, where land is the communal property of all members of a community, every individual from later generations to future generations; and,

(ii) Public aspect, where in owning communally the land there is an authority or competence to "manage, govern and organize control, maintenance, allocation and use." 72

The authority of a public nature occurring from the right of allocation construction is basically in the hand of the community as an entity. However, its day-to-day exercise is entrusted to adat chiefs or adat elders as legal functionaries. ${ }^{73}$ This authority is solely and entirely public in nature i.e. "does not cover and influence the legal relations to the communal land of a private nature." Ownership over communal land, with the exercise of authority by the legal functionaries, stays in the hand of the community as an entity and individual members of the community, and does not transfer to adat chiefs or adat elders. ${ }^{74}$

69 Ibid. 180. See also Section 2.2, notice the close similarities between this argument with that of Supomo's. The relevance of customary inheritance law is evident in legal, social, and cultural problems faced by various ethnic groups in Indonesia. Regarding contemporary customary inheritance law of Besemah, See Dewi Sukarti, "Customary Law of Inheritance and Migration: Adoption of The Old Regime or Adaptation to The New One?" Ahkam 17, no. 2 (2017). See also a non-mainstream views on the Balinese women's right to inherit in Hanna Christine Ndun, Sarah Suttor, and I Gusti Agung Ayu Dike Widhiyaastuti, "Does Customary Law Discriminate Balinese Women's Inheritance Rights?." Udayana Journal of Law and Culture 2, no. 1 (2018): 97-114.

70 Ibid., 205-206.

71 Ibid., 181.

72 Ibid., 182.

73 Ter Haar .B. Asas-Asas dan Susunan Hukum Adat. Transl. Subakti Pusponoto. (Jakarta: Pradnja Paramita, 1985), 275. On adat chief and adat elders as legal functionaries, see also Keebet von BendaBeckmann, "Forum Shopping and Shopping Forums: Dispute Processing in a Minangkabau Village in West Sumatra." Journal of Legal Pluralism 13, no.19 (1981):131.

74 Budi Harsono. Op.Cit, 182-183. 


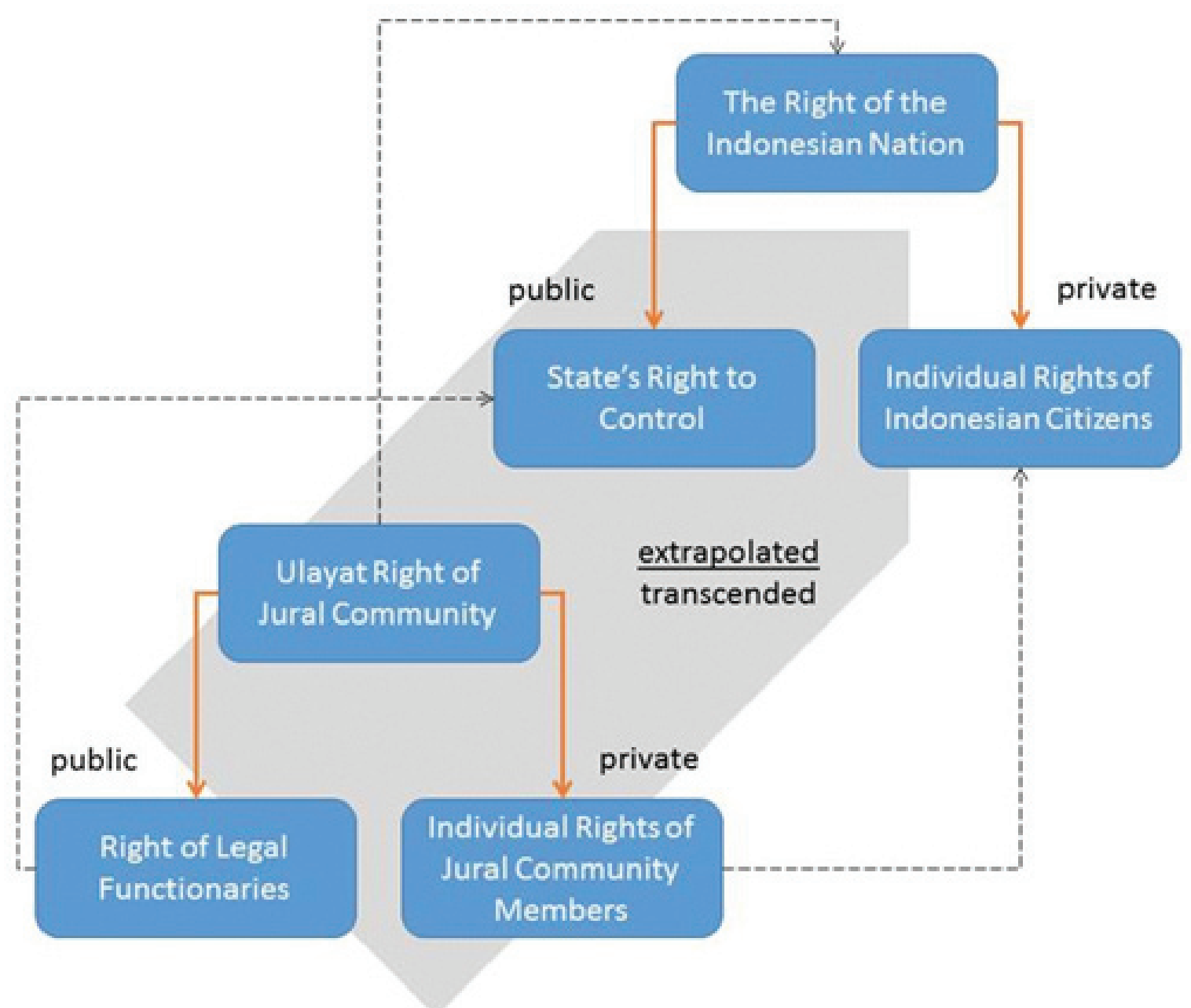

\section{Figure2. Application of Adat Land Law Concept to National Land Law}

Based on this concept, "Adat land law contains legal stipulations that belong to private land law and administrative land law," that result to "a structure and hierarchy of rights over land in Adat Law" as follows.

1. Communities' Right, "as the highest right to control, having both private and public aspects."

2. Rights of legal functionaries, "that originate from the public aspect of Communities' Right."

3. Individual Rights of Community Members, which are entirely private in nature."75

If this Adat land law concept is applied to national land law, the resulting systematics of land rights shall be as follows. ${ }^{76}$

\footnotetext{
75 Ibid., 183.

76 Ibid., 208-209.
} 
1. The Right of the Nation; as the highest right to control over the entire territory of the Unitary Republic of Indonesia, having both private and public aspects. ${ }^{77}$

2. State's Rights to Control; that originate from The Right of the Nation which covers only its public aspect. ${ }^{78}$

3. Individual Rights of Indonesian citizens, which are entirely private in nature. ${ }^{79}$

These unique concepts are indeed difficult to comprehend from a "Western" point of view that understands land as a mere production factor or commercial commodity.Thorburn perhaps is a rare example of western observers who manages to comprehend the concepts as they are. By grasping the two fundamental concepts of (i) inalienability of land from the people; and, (ii) the social function of land, he understands that the vision of Indonesian land law is that where all Indonesian citizens as an entity of "National Community" communally own the territory of the Unitary Republic of Indonesia along with all natural resources therein as "National Ulayat Right," 1 while the State of the Republic of Indonesia act as the Legal Functionary-or, in the wordings of BAL, "the organization of the people's sovereignty"-in managing, governing and organizing its control, maintenance, allocation and use. ${ }^{82}$

The development in the recent decade shows interesting progress. Academic and political debates on the issue of ownership over communal land was ultimately addressed in a legal context, following the judicial review of Indonesian Foresty Law before the Constitutional Court of the Republic of Indonesia, as requested by Aliansi Masyarakat Adat Nusantara (AMAN; Nusantara Indigenous People Alliance) et.al. ${ }^{83}$ The petition contends that the inclusion of hutan adat (customary forest) within hutan negara (State forest) area was unconstitutional. ${ }^{84}$ The Constitutional Court considers that hutan adat must be categorized as that of hutan hak (forest subject

77 BAL, Art. 1 .

78 BAL, Art. 2.

79 BAL, Art. 4.

80 The term "Western" here actually is only a reference to the dichotomy in classic Adat Law discourse between "adat" or "Orient" and "Western". In fact, what is termed as "Western" here is more correct if understood as "liberal capitalist." On this, see, for example, David Bourchier, "The Romance of Adat in the Indonesian Political Imagination and the Current Revival," in The Revival of Tradition in Indonesian Politics: The Deployment of Adat from Colonialsm to Indigenism, ed. Jamie S. Davidson and David Henley (Oxon, New York: Routledge, 2007), 114.

81 Craig C. Thorburn, "A long Row to Hoe: Decentralization, Reformasi, and Land Management Policy in Indonesia," Asia Pacific Viewpoints 45, no. 1 (2004); 35-37. The notion "State Ulayat Right" which Fitzpatrick claimed as other name for state's right of control is therefore incorrect. See Daniel Fitpatrick, "Beyond Dualism: Land Acquisition and law in Indonesia" in Indonesia Law and Society, ed. Tim Lindsey, Fully Revised and expanded 2nd Edition. (Singapore: The Federation Press, 2008), 236. The fact that there are practices of unconsented land acquisition by government does not necessarily mean that such conducts are theoretically and legally justifiable.

83 Decision of the Constitutional Court of the Republic of Indonesia, No. 35/PUU-X/2012, para 1.2.

84 Mirza Satria Buana,Ph.D diss, Op.Cit., 98. 
to right) instead of hutan negara. ${ }^{85}$ In its ruling, the Constitutional Court has declared as invalid the Indonesian government's claim to millions of hectares of forest land, potentially giving indigenous and local communities the right to manage their customary forests. ${ }^{86}$ This landmark ruling was unanimously decided by all (nine) judges, without any single dissenting opinion. Although this decision was considered 'a win' for customary community advocates, the Court was also criticized as it has left substantial legal stumbling blocks in the way of most traditional communities seeking to enjoy the traditional rights to which they are constitutionally entitled. ${ }^{87}$

As previously described in Section 1.1, Second Amendment of the 1945 Basic Law, Basic Agrarian Law, and Forestry Law have recognized traditional rights of jural communities in Indonesia, including, inter alia, the so-called hak ulayat (beschikkingsrecht; right of allocation). Such right has also given a human rights character as it is stipulated in Indonesia Human Rights Law. ${ }^{88}$ The 2016 Regulation of Minister of Agrarian Affairs made a progress in terms of the rights to the land of jural community. ${ }^{89}$ It admits that jural community-that has fulfilled specific requirements - may be entitled to land rights in the form of communal rights. ${ }^{90}$ This regulation makes clear that there is no individual claim made by a member of a jural community as communal rights to land is defined as a collective/common property rights over jural community lands. ${ }^{91}$

Budi Harsono's statement that BAL is the "first product" of the development of national [land] law that uses the ingredients of Adat Law, that "[is] formulated in the structure and system of Adat Law,"92 is particularly noteworthy. This statement implied that other fields of law, both related or not to land law, can be formulated according to the system of Adat Law, and that they are only waiting for their turns! Suryono Sukanto also has the same conviction. He criticized that ethnological, anthropological and sociological-and, corollary, inductive-approaches are recommended for Adat Law jurisprudence, only when adat law is understood as the

85 Ibid., para 3.13.4. Mia Siscawati, “Overview of Forest Tenure Reforms in Indonesia," Working Paper 223, Bogor Barat: Center for International Forestry Research (CIFOR), 2017: 10 however, understands hutan hak as "private forest" hutan negara as "State forest."

86 Rhett A. Butler, "In Landmark Ruling, Indonesia's Indigenous People Win Right to Millions of Hectares of Forest" May 17, 2013 <https://news.mongabay.com/2013/05/in-landmark-ruling-indonesias-indigenous-people-win-right-to-millions-of-hectares-of-forest/>

87 Simon Butt, 'Traditional Land Rights before the Indonesian Constitutional Court', Law, Environment and Development Journal 10, no.1 (2014): 57.

88 Law No. 39 Year 1999 concerning Human Rights, Art. 6.

89 Regulation of Minister of Agrarian and Spatial Affairs / Head of the National Land Agency of the Republic of Indonesia Number 10 Year 2016 concerning the Procedures for the Establishment of Communal Rights on Jural Communities' Land and Communities that are in Specified Area.

90 Ibid., Arts. 2 (1) and 3(1).

91 Ibid., Art. 1.

92 Budi Harsono, Op.Cit., 208. 
"living law"93 i.e. law that "lives" among the people—or, in other words, customary law. For Suryono Sukanto, a normative-deductive approach is also necessary to achieve completeness in a more sophisticated systematics of law, that covers (i) public laws and private laws; and, (ii) substantial laws and procedural laws. ${ }^{94}$

Besides, by summoning the help of Ter Haar's Decision Theory-that adat law may originate from both the decisions of legal functionaries and community members as well, and that the decisions of legal functionaries pertain to public interests so they are imperative in nature, while the decisions of community members pertain to private interests so they are facultative in nature-he argued that "it is certain that [division into public laws and private laws] is applicable to adat law as well." ${ }^{95}$ Suryono Sukanto, therefore, includes "Hukum Tantra" or Staatsrecht that consists of constitutional and administrative law in his systematics of law, "at least, as a jurisprudence. [i.e. Adat Law jurisprudence]"96

In fact, if that is Suryono Sukanto's actual intention-breaking through traditional and conventional obstacles of Adat Law jurisprudence to use it as ingredients in developing the national legal system-then BAL and Budi Harsono have succeeded brilliantly to a very great extent. BAL, supported by Budi Harsono's theoretical justification, has managed to extrapolate and transcend adat law to a higher and wider plane i.e. the national legal system of Indonesia. Unique categories of Adat Law i.e. (i) the communalist-religious concept of Adat Law, that transcends into a national communalist-religious; and, (ii) the role and status of legal functionaries in a jural community; are proven to be potential in developing legal theories that is uniquely Indonesian, and, most importantly, in harmony with the worldview of Indonesians.

Pertaining to constitutional and administrative law, the theory of the role and status of Indonesian State in an Indonesian national community that is parallel with the role and status of legal functionaries in their concerning communitiesthat is formulated by BAL as the "organization of people's sovereignty"-may serve as a starting point to build legal theories and practices in the fields of constitutional and administrative law that are uniquely Indonesian, in accordance with the needs of Indonesian national community. Furthermore, should Indonesian lawyers genuinely and sincerely wish to do so, Adat Law-as the "aseli" (autochthonous) law of Indonesians, as demonstrated by BAL—provides more than enough inspiration and ingredients to build Indonesia's own national legal system and theories.

93 Franz Von Benda-Beckmann and Kebet Von Benda-Beckmann, "The Social Life of Living Law in Indonesia" in Living Law. Reconsidering Eugen Ehrlich, ed. Marc Hertogh (Oxford, Portland: Hart Publishing, 2009), 180.

94 Surjono Sukanto. Op.Cit. 120-121. In this regard, Suryono Sukanto also does not directly rebut Supomo's (1962) theory that Adat Law does not recognize a distinction between public laws and private laws vide Supomo. (1962) Op.Cit., 2-3.

95 Surjono Sukanto. Op.Cit. 121.

96 Ibid., 122. He even went as far as dedicating a separate discussion on "Hukum Negara" or Staatsrecht under the Chapter "Adat Law: An Analytical Description" vide Ibid. 137-163. 


\section{Conclusion}

From the very beginning, Adat Law scholarship had a pragmatic purpose i.e. to administer justice and govern the colony, the NEI. Hence, its very nature was public, which is in contrast with its later development that focused on private law fields such as the law of persons, marriage and family laws, property and inheritance laws. Due to this later development, particularly after World War Two and in postindependence Indonesia, the relation between Adat Law and public laws was obscured. In fact, the 1945 Constitution main architect was Indonesia's leading Adat Law scholar, Supomo-hence, the Constitution is, to say the least, heavily inspired by Adat Law. It is not exaggerating at all to say that one can never comprehend the Constitution without sufficient insight on Adat Law. In other words, Indonesian constitution is actually an "Adat" constitution.

The same goes to administrative law, which in this case is represented by BAL that governs not only land administration, but all kinds of natural resources in Indonesia until nowadays. Just like the 1945 Constitution, one will surely fail miserably to understand this Law should one does not have an acceptable command of Adat Law. It is, however, must be quickly added that, in doing so, a clear distinction must be made between Adat Law and adat laws, with the former refers to theories and concepts resulting from deductive examination of findings in research concerning the laws that actually live among the people, while the latter is the multitude laws that actually live among the multitude people of Indonesia themselves. Failure in understanding this difference will certainly mislead one to understand the true and actual position of Adat Law in Indonesia's national legal system. 


\section{BIBLIOGRAPHY}

\section{Book}

Bourchier, D. Illiberal Democracy in Indonesia:The Ideology of the Family State. London: Routledge, 2015.

Burns, Peter. The Leiden Legacy. Concepts of Law in Indonesia. Leiden: KITLV Press, 2004.

Bushar Muhammad. Asas-Asas Hukum Adat. Suatu Pengantar. Ed. IX. Jakarta: Pradnja Paramita, 1994.

Dewan Pertimbangan Agung RI. Tudjuh Bahan Pokok Indoktrinasi. Jakarta: DPA RI, 1961.

Elson, Robert Edward. The Idea of Indonesia. A History. Cambridge: Cambridge University Press, 2008.

Harsono, Budi. Hukum Agraria Indonesia. Sejarah pembentukan Undang- Undang Pokok Agraria, Isi dan Pelaksanaannya. Jilid 1 Hukum Tanah Nasional. Cet. IX. Jakarta: Djambatan, 2003.

Holleman, J.F. (Ed.) Van Vollenhoven on Indonesian Adat Law. Dordrecht: Springer Science, Business Media, 1981.

Hooker, Michael Barry. Adat Law in Modern Indonesia. Oxford: Oxford University Press, 1979.

Joyodiguno, M.M. Reorientasi Hukum dan Hukum Adat. Jogjakarta: PT.Penerbit Universitas, 1961.

Koesnoe, Moh. Hukum Adat sebagai Suatu Model Hukum. Bagian I (Historis). Bandung: Mandar Maju, 1992.

Simanjuntak, Marsilam. Pandangan Negara Integralistik: Sumber, Unsur dan Riwayatnya dalam Persiapan UUD 1945. Jakarta: Pustaka Utama Grafiti, 1994.

Soemadiningrat, Otje Salman. Rekonseptualisasi Hukum Adat Kontemporer. Bandung: Alumni, 2002.

Sudiyat, Iman. Asas-Asas Hukum Adat: Bekal Pengantar. Ed.III. Yogyakarta: Liberty, 2000. 
Supomo. Kedudukan Hukum Adat di Kemudian Hari. Jakarta: Pustaka Rakyat, 1959.

Supomo. Bab-bab tentang Hukum Adat. Jakarta: Penerbitan Universitas, 1962.

Sukanto, Suryono and Soleman Taneko. Hukum Adat Indonesia. Cet. VI.Jakarta: RajaGrafindo Persada, 2003.

Ter Haar. B. Asas-Asas dan Susunan Hukum Adat. Transl. Subakti Pusponoto. Jakarta: Pradnja Paramita, 1985.

\section{Chapter in an Edited Book}

Bourchier, David. "The Romance of Adat in the Indonesian Political Imagination and The Current Revival." In The Revival of Tradition in Indonesian Politics: The Deployment of Adat from Colonialism to Indigenism, edited by Jamie S. Davidson and David Henley. Oxon, New York: Routledge, 2007.

Fasseur, Cess. "Colonial Dilemma: Van Vollenhoven and the Struggle Between Adat Law and Western Law in Indonesia." In European Expansion and the Law, edited by Wolfgang J. Mommsen and Jaap A. de Moor. Oxford/New York: Berg, 1990.

Fitzpatrick, Daniel. "Beyond Dualism: Land Acquisition and law in Indonesia." In Indonesia Law and Society, edited by Tim Lindsey, Fully Revised and expanded $2^{\text {nd }}$ Edition. Singapore: The Federation Press, 2008.

Supomo. "The Future of Adat Law in the Reconstruction of Indonesia." In Southeast Asia in the Coming World, edited by Philip Warren Thayer. Baltimore: John Hopkins Univesity Press, 1957.

Von Benda-Beckmann, Franz and Keebet Von Benda-Beckmann. "The Social Life of Living Law in Indonesia." In Living Law. Reconsidering Eugen Ehrlich, edited by Marc Hertogh, 177-197. Oxford, Portland: Hart Publishing, 2009.

Wahyudi, Agus. "Human Rights and Corruption: Indonesian Case for Reconciling Universalism and Relativism." In Human Rights and the Third World: Issues and Discourses, edited by Subrata Sankar Bagchi and Arnab Das, 81-98. Lanham: Lexington Books, 2013.

\section{Journal Article}

Agusman, Damos Damoli “The Dynamic Development on Indonesia's Attitude toward International Law." Indonesian Journal of International Law 13, no. 1 (2015): 1-31. DOI: http://dx.doi.org/10.17304/ijil.vol13.1.624 
Buana, Mirza Satria. "Living adat Law, Indigenous Peoples and the State Law: A Complex Map of Legal Pluralism in Indonesia," International Journal of Indonesian Studies 1, no. 3 (2016): 104-119.

Butt, Simon. "Traditional Land Rights before the Indonesian Constitutional Court", Law, Environment and Development Journal 10, no.1 (2014): 57-73.

Engel, David M. "Adat Law in Modern Indonesia." The American Journal of Comparative Law 28, no. 2 (1980): 352 354, https://doi.org/10.2307/839892

Fenrich, Jeanmarie and Mary McEvoy. "Promoting Rule of Law in Customary Tribunals in Ghana," Harvard Human Rights Journal 11 (September 2014)

Fitzpatrick, Daniel. "Disputes and Pluralism in Modern Indonesian Land Law," Yale Journal of International Law 22, no. 1 (1997): 171-212.

Gillespie, John. "Public Discourse and Constitutional Change: A Comparison of Vietnam and Indonesia." Asian Journal of Comparative Law 11, no. 2 (2016): 209-218. https://doi.org/10.1017/asjcl.2016.17

Gold, Martin E. and Russell B. Zuckerman. "Indonesian Land Rights and Development," Columbia Journal of Asian Law 28, no. 1 (2014)

Miranda, Lillian Aponte. "Indigenous Peoples as International Lawmakers," University of Pennsylvania Journal of International Law 32, no. 1 (2010): 203.

Mosses, Morsen. "Custom as a Source of Law in Vanuatu: A Critical Analysis," Journal of South Pacific Law, Special Edition (2017): 37-54.

Napoh, Datu Bua. "Recognition of the Customary Land Law in the Constitution of Indonesia and Malaysia," Brawijaya Law Journal 2, no.2 (2015): 1-19.

Ndun, Hanna Christine, Sarah Suttor, and I Gusti Agung Ayu Dike Widhiyaastuti. "Does Customary Law Discriminate Balinese Women's Inheritance Rights?." Udayana Journal of Law and Culture 2, no. 1 (2018): 97-114. https://doi. org/ 10.24843/UJLC.2018.v02.i01.p05

Nurjaya, I Nyoman. "Is The Constitutional and Legal Recognition of Traditional Community Laws within the Multicultural Country of Indonesia: A Genuine or Pseudo Recognition?," Constitutional Review 1, no.2 (2015): 49-68.

Perry, Robin. "Balancing Rights or Building Rights? Reconciling the Right to Use Customary Systems of Law with Competing Human Rights in Pursuit of Indigenous Sovereignty," Harvard Human Rights Journal 24, no.1 (2011): 71-114. 
Reid, Anthony. "Political "Tradition" in Indonesia: the One and the Many." Asian Studies Review 22, no. 1 (1998): 23-38.

Sukarti, Dewi. "Customary Law of Inheritance and Migration: Adoption of The Old Regime or Adaptation to The New One?" Ahkam 17, no. 2, (2017): 301-320. https://doi.org/10.15408/ajis.v17i2.6236

Sukiati. "Hazairin's Legal Thought And His Contribution Towards The Indonesian Legal System," Journal of Indonesian Islam 6, no.1 (2012): 93-124.

Thorburn, Craig C. "A Long Row to Hoe: Decentralization, Reformasi, and Land Management Policy in Indonesia," Asia Pacific Viewpoints 45, no. 1 (2004): 33-49.

Von Benda-Beckmann, Franz. and Keebet Von Benda-Beckmann. "Myths and Stereotypes about Adat Law. A reassessment of Van Vollenhoven in the Light of Current Struggles over Adat Law in Indonesia." Bijdragen tot de Taal, Land en Volkenkunde 167, no. 2-3 (2011): 167-195. https://doi.org/10.1163/22134379-90003588

Von Benda-Beckmann, Keebet. "Forum Shopping and Shopping Forums: Dispute Processing in a Minangkabau Village in West Sumatra." Journal of Legal Pluralism 13, no. 19 (1981): 117-159. https://doi.org/10.1080/07329113.1981.10756260

Szczepanski, Kallie. "Land Policy and Adat Law In Indonesia's Forests," Pacific Rim Law \& Policy Journal 11, no. 1 (2002): 231-255.

\section{Dissertation}

Buana, Mirza Satria."State Courts, Traditional Dispute Resolution and Indigenous Peoples in South Kalimantan: A Socio-Legal Study.” Ph.D diss., TC Beirne School of Law, University of Queensland, 2017.

\section{Conference Proceeding}

Muhammadin, Fajri and Danusatya, Hanindito, 2017. "De-Secularizing Legal Education in Indonesia: Examining the 'Introduction to Jurisprudence' Textbooks on Norm Classification" in E-Proceedings International Seminar on Islamic Civilization and Thoughts, November 20, 2017, 51-59, Pulau Pinang:School of Humanities Universiti Sains Malaysia

\section{Legal Documents}

The 1945 Constitution of the Republic of Indonesia.

Law Number 5 Year 1960 on the Basic Regulation on the Essentials of Agrarian Affairs. 
Law Number 41 Year 1999 on Forestry.

Law Number 39 Year 1999 on Human Rights

Law Number 18 Year 2004 on Plantation.

Law Number 39 Year 2014 on Plantation.

Regulationof the Ministry of Environmental Affairs and Forestry Number P.32/

Menlhk-Setjen/2015 on Forests Subject to Rights.

Regulation of Minister of Agrarian and Spatial Affairs / Head of the National Land Agency of the Republic of Indonesia Number 10 Year 2016 concerning the Procedures for the Establishment of Communal Rights on Jural Communities' Land and Communities that are in Specified Area

Circular of the Ministry of Forestry Number SE.1/Menhut-II/2013.

\section{Other Document}

Sekretariat Negara RI. (1992) Risalah Sidang Badan Penyelidik Usaha-Usaha Persiapan Kemerdekaan dan Panitia Persiapan Kemerdekaan Indonesia. Jakarta: Sekretariat Negara RI.

\section{Case Law}

Constitutional Court of the Republic of Indonesia Decision No. 35/PUU-X/2012.

\section{Website Content}

Ompusunggu, Moses, 'Adat' communities want their own special law: Why?, The Jakarta Post, May 11, 2018. 